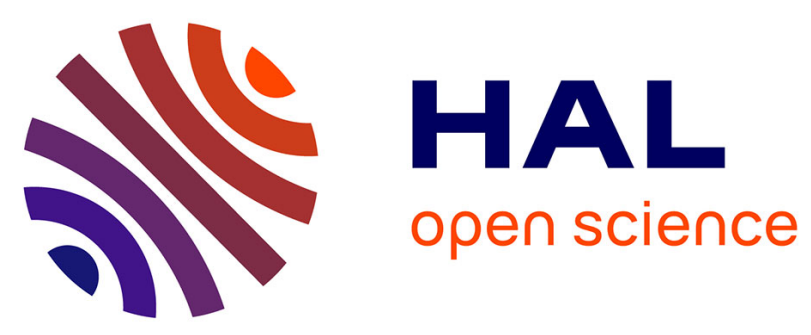

\title{
Influence of the bituminous layer on temperature and water infiltration in railway structures of the Bretagne-Pays de Loire High-Speed line
}

Diana Khairallah, Juliette Blanc, Pierre Hornych, Jean Michel Piau, Louis Marie Cottineau, Simon Pouget, Alain Ducreau, Fréderic Savin, Mohsen Hosseingholian

\section{To cite this version:}

Diana Khairallah, Juliette Blanc, Pierre Hornych, Jean Michel Piau, Louis Marie Cottineau, et al.. Influence of the bituminous layer on temperature and water infiltration in railway structures of the Bretagne-Pays de Loire High-Speed line. Journal of Testing and Evaluation, 2020, 48 (1), p. 134-149. 10.1520/JTE20180894 . hal-03121804v2

\section{HAL Id: hal-03121804 \\ https://hal.science/hal-03121804v2}

Submitted on 17 Feb 2022

HAL is a multi-disciplinary open access archive for the deposit and dissemination of scientific research documents, whether they are published or not. The documents may come from teaching and research institutions in France or abroad, or from public or private research centers.
L'archive ouverte pluridisciplinaire HAL, est destinée au dépôt et à la diffusion de documents scientifiques de niveau recherche, publiés ou non, émanant des établissements d'enseignement et de recherche français ou étrangers, des laboratoires publics ou privés. 


\section{Influence of the bituminous layer on temperature and water infiltration in railway structures of the Bretagne - Pays de la Loire High-Speed line.}

Khairallah Diana ${ }^{a *}$, Blanc Juliette ${ }^{\mathrm{b}}$, Hornych Pierre ${ }^{\mathrm{b}}$, Jean-Michel Piau ${ }^{\mathrm{b}}$, Louis-Marie Cottineau ${ }^{\mathrm{b}}$, Simon Pouget ${ }^{\mathrm{c}}$, Alain Ducreau ${ }^{\mathrm{d}}$, Frederic Savin $^{\mathrm{e}}$, and Mohsen Hosseingholian ${ }^{\mathrm{a}}$

${ }^{a}$ Railenium, Valenciennes, France, diana.khairallah@ railenium.eu ; ${ }^{b}$ IFSTTAR, Bouguenais, France ; Eiffage, Corbas, France ; ${ }^{d}$ SNCF Reseau, Nantes, France ; ${ }^{e}$ Setec, Paris, France

Provide full correspondence details here including e-mail for the *corresponding author Provide short biographical notes on all contributors here if the journal requires them.

In : Journal of Testing and Evaluation, 48, 1, 2020, American Society for Testing and Materials - ASTM, p. 134-149 


\section{Influence of the bituminous layer on temperature and water infiltration in railway structures of the Bretagne - Pays de la Loire high-speed line.}

The phenomena of settlement and wear of the ballast under dynamic stresses lead to high frequencies and high maintenance costs on high speed railway lines. Studies have shown that these settlements are linked to high accelerations produced in the ballast by the passage of high-speed trains (HST). A layer of asphalt concrete (GB) was introduced under the ballast layer on the high-speed line Bretagne-Pays de Loire (BPL HSL). It is intended, among other things, to reduce the amplitude of accelerations produced at the passage of the HST, and thus improve the durability of the track.

The BPL HSL spans $105 \mathrm{~km}$ with a sub-layer of asphalt concrete under the ballast, and $77 \mathrm{~km}$ with a granular sublayer (UGM). To evaluate the performance of the structures with bituminous sublayer, and to compare it with traditional structures, with granular sublayer, 4 track sections have been instrumented during construction. This article presents the different sensors of the instrumentation as well as the acquisition system installed to collect measurements. The focus, in this study, concerns the temperature, water content and vertical settlement measurements made on the instrumented sections. Temperature variations recorded during two years on the railway structure with bituminous sublayer were analysed and compared to those measured on a classical bituminous pavement. Influence of the bituminous layer on water infiltration and track settlements has also been studied.

Keywords: Ballasted railways, asphalt concrete, monitoring, water infiltration, temperature.

\section{Introduction}

In France, the structures of high-speed rail lines (HSL) are generally made of ballast, resting on a sub-layer of granular materials. Studies have shown that ballast settlements result from high accelerations produced in the ballast due to high-speed trains [1-4]. One of the proposed solutions to mitigate this problem was to introduce an asphalt concrete layer under the ballast layer [5]. This solution has been implemented on the 
HSL Bretagne-Pays de Loire (BPL). The BPL HSL includes $105 \mathrm{~km}$ of track with asphalt concrete sub-layer under the ballast and $77 \mathrm{~km}$ of standard granular layer (see Figure 1).

Bituminous underlayment was used since the 1980s in several countries like the United States, Italy and Spain, especially on high-traffic and high-speed lines [6]. It offers several advantages: improvement of the stiffness of the platform supporting the ballast, limited risks of settlement, reduction of the thickness of the structures, improved soil moisture protection, ease of construction (the bituminous layer creates a stiff construction platform facilitating the movement of construction equipment on site). In order to better understand the mechanical behavior of the track structure under train loading, and the improvements to the track structure when the bituminous layer is placed in the track, four sections of the HSL were instrumented. It was intended also to prove the ballast role regarding temperature fluctuations. This instrumentation is a collaborative project in partnership with IRT Railenium, Eiffage, IFSTTAR, SNCF Reseau, SETEC and the University of Lille.

The four selected sections represent the different types of structures of the new BPL high-speed lane (2 rectilinear sections and 1 curve section with a $12 \mathrm{~cm}$ asphalt concrete sub-layer, and 1 section with granular sub-layer), and have been instrumented with a total of approximately 100 sensors of different types. The development and installation of the instrumentation was carried out by IFSTTAR with the support of Eiffage Infrastructures.

The general objective of the instrumentation is to study the mechanical response of the different experimental sections under the effect of train speeds and loads [7-10], and under variable climatic conditions (temperature, water conditions). The measurements 
include acceleration, strain and displacement measurements under the passage of the trains, "slow measurements" of track settlements, and environmental parameters. In this article, the "slow measurements", like the evolutions of the temperature, moisture and deflection of the structures are presented as well as a comparison of temperature fluctuations between rail and road pavements.

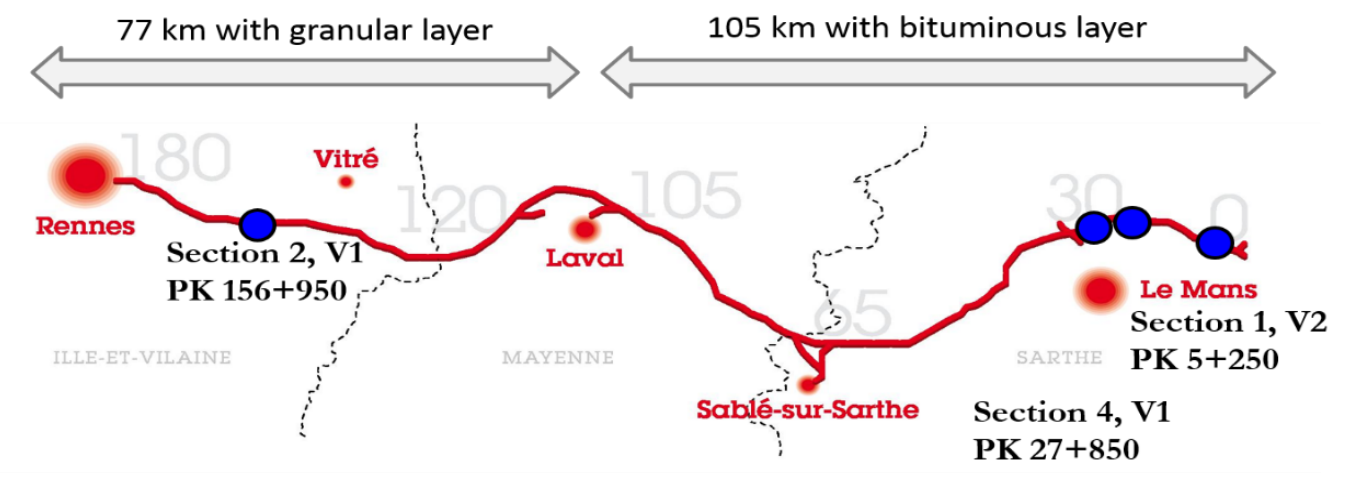

Figure 1. Location of the 4 instrumented sections

\section{Instrumentation of BPL Track}

\section{Sensors and Measurements}

One of the objectives of this instrumentation is to obtain a database of dynamic and mechanical measurements of the response of the different structures used on the BPL line (mainly the subgrade and granular or bituminous sub-layers): accelerations, displacements of the ballast structure, horizontal and vertical deformations in different layers, layers and air temperatures, water content of the layers.

Both conventional and bituminous tracks were instrumented with a weather station for each section, accelerometers embedded at different levels in the structure and placed on sleepers, vertical extensometers in the UGM sublayer, two anchored displacement sensors on each section, moisture probes, and temperature probes. The bituminous track was also equipped with longitudinal and transversal strain gauges placed at the bottom of the bituminous layer to validate the design hypothesis of strain levels in the 
bituminous layer. The measurements of the anchored displacement sensors, temperature sensors, moisture probes and weather station represent the focus of this article. The humidity probes used are Campbell Scientific CS650-DS, the temperature probes PT100: KIMO Instrumentation and the anchor deflection sensors are LVDT (Linear Variable Differential Transformer) 4-20mA.

An example of the instrumentation plan of section 4 (indicating only the sensors studied in this paper) is shown in Figure 2, in plan view, while a detailed description of all the instrumentation has been provided in the published papers [11-12].

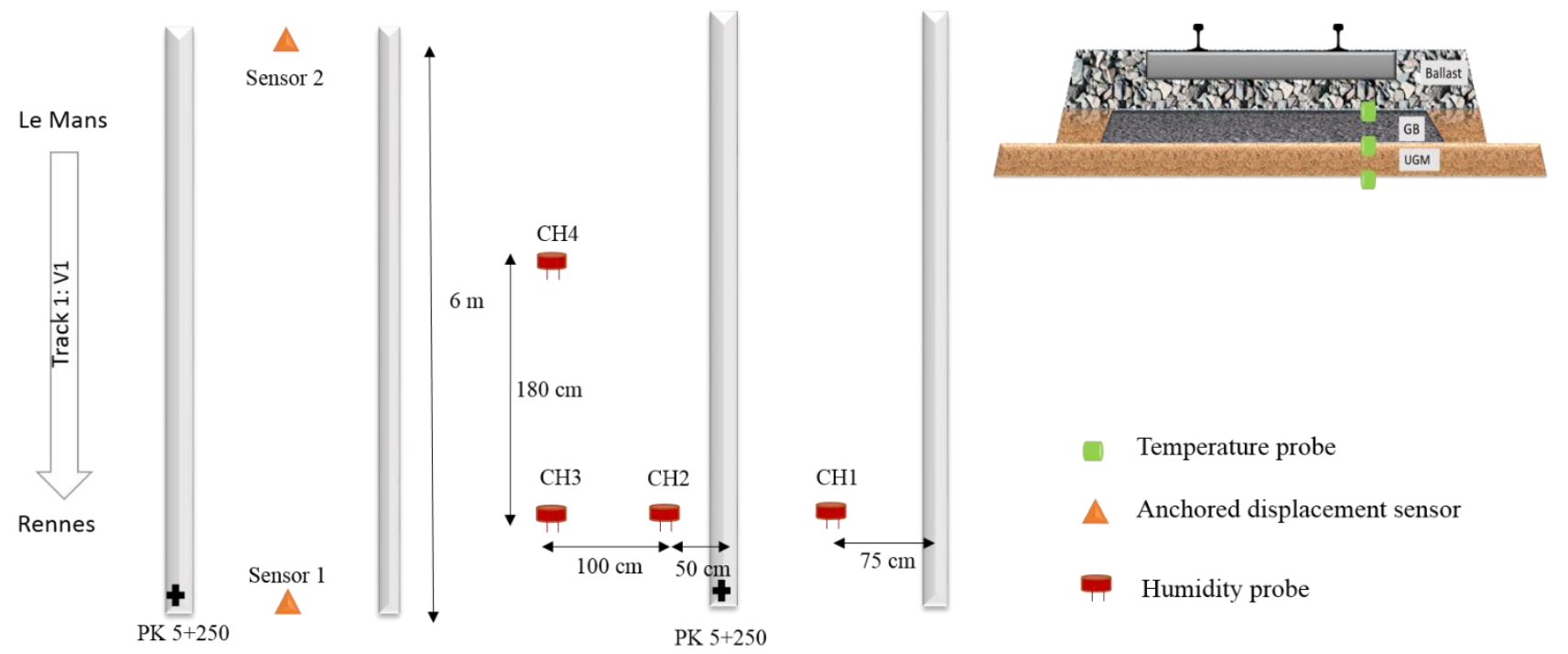

Figure 2. Instrumentation plan of section 4

At the level of each section, two types of measurements are made: "slow" measurements and "fast" measurements. Slow measurements include temperature sensors, water content probes, weather data, anchored deflection sensors (measurement of the overall vertical settlements of the ballast sub-structure). These are recorded every 15 minutes.

Fast measurements include accelerometers, vertical extensometers, horizontal extensometers and the anchored displacement sensors (measurement of the displacement under a train passage). These measurements are carried out at each train 
crossing. They are triggered if a threshold value is exceeded (threshold set for an accelerometer placed at the top of the first sublayer). The threshold has been set at a very low value to allow the recording of all trains' passages. The signal acquisition frequency is $2000 \mathrm{~Hz}$. All measurements, whether slow or fast, are dated in GPS time indicated in hour-minute-second-microsecond.

\section{Acquisition system}

The mentioned sensors are connected by cables to the measurement acquisition systems. Based on its performance and feedback collected from previous experiments, an acquisition system using Pegase boards [13-14], developed by IFSTTAR was selected. Boxes containing the Pegase data acquisition boards, connected to their supported sensors, are in place at each section.

Each system is autonomous in energy and data transmission. Power is generated by Solar panels and batteries and supplied to the acquisition systems for continuous yearround functioning. As access to the site is highly restricted, the acquisition system had to be controlled and programmed remotely. Data are transmitted via 3G/4G network to a remote server within few hours. A picture of one of the instrumented sections is presented in Figure 3. It is possible to see the solar panel, the boxes with the battery, the case containing the acquisition system (behind the solar panels) and the weather station at the top. 


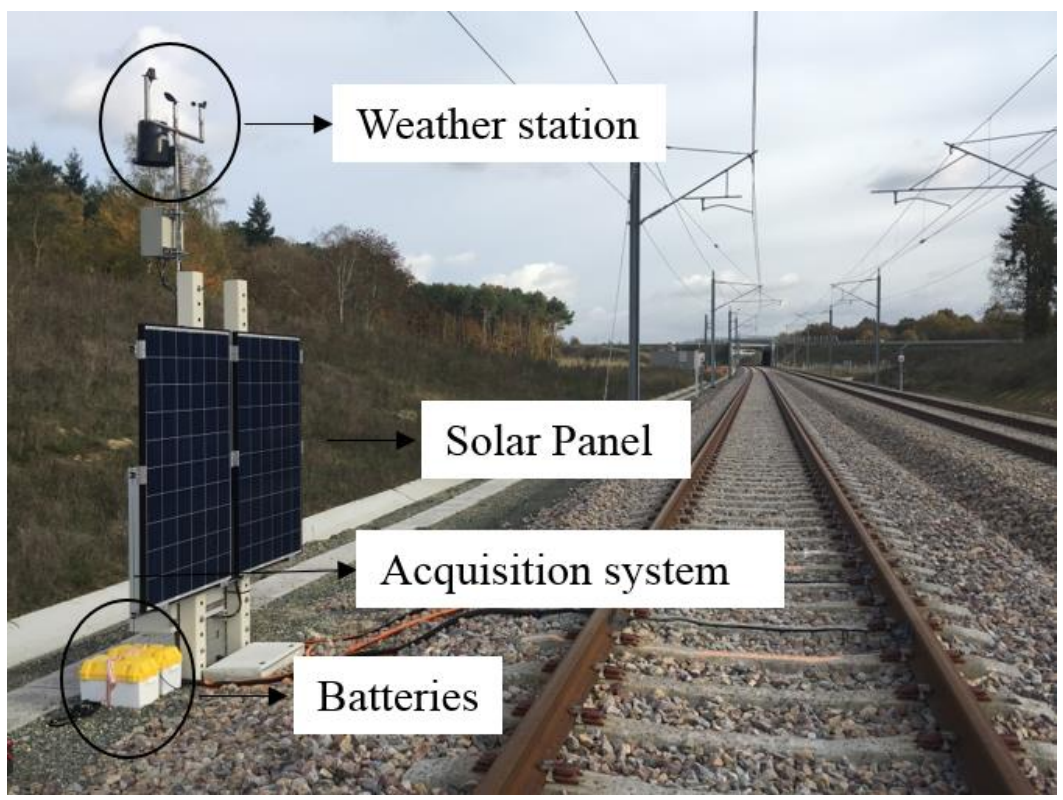

Figure 3. Acquisition system and weather station

All recorded data are stored into a relational database for a fast and multi-criteria data search. A remote webserver allows management of the various instrumented sites as well as the different measurement systems of each site, including the weather station system, the water content measurements and the configurations of the different acquisition parameters, through a web application.

The address of the server is secure https with login and password and different levels of access (all rights, account administrator and system configuration, simple user allowing visualization of the data and export). It provides the different partners of the project with access to real-time data. This includes visualizing the curves of slow and fast measurements and exporting and downloading measurements for any date or train passage.

\section{Instrumented sections}




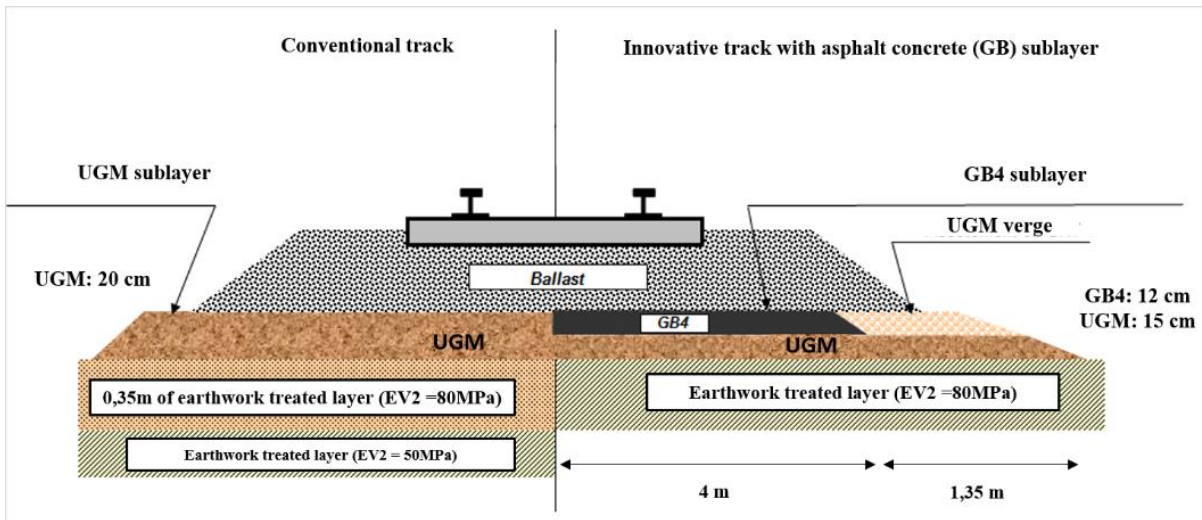

Figure 4. Different structures of the HSL BPL

Figure 4 compares the traditional cross section, with a granular sub-ballast layer, used in the BPL HSL with the asphalt sub-ballast layer in the $105 \mathrm{~km}$ innovative section. The traditional structure consists of a $30 \mathrm{~cm}$ thick ballast layer on $20 \mathrm{~cm}$ of unbound granular material (UGM type A, particle size $0 / 31.5 \mathrm{~mm}$ ) sub-ballast layer. This ballast and sub-ballast layers rest on a $35 \mathrm{~cm}$ cement-treated granular layer. In the alternative with the asphalt sub-ballast layer, the $35 \mathrm{~cm}$ thick treated layer is replaced by a $12 \mathrm{~cm}$ asphalt concrete sub-ballast layer and a $15 \mathrm{~cm}$ thick granular layer (UGM A 0/31.5 $\mathrm{mm})$.

The asphalt concrete (GB) sub-ballast layer is a high performance base course asphalt material, of class 4 (GB4) according to the NF EN 13-108-1 standard, with a maximum aggregate size of $14 \mathrm{~mm}$. It is applied over the track cross section with a width of $8 \mathrm{~m}$. Starting from GB, a $1.35 \mathrm{~m}$ of coating layer is installed under ballast to protect the beneath granular layer.

Three instrumented sections are analysed in this paper: section 2, with the classical structure with a granular sublayer, and sections 1 and 4, with the innovative structure with asphalt concrete sublayer. The soil beneath the earthwork treated layer consists of shale on section 2 (granular sublayer) and of yellowish clay with a broad sandy channel 
and scattered blocks on section 4 (bituminous sublayer). Sections 2 and 4 are built on embankments. No water infiltration was detected in these two clay sections when two $6.5 \mathrm{~m}$ deep drillings were performed (September 2015). On the contrary, Section 1 with bituminous sublayer, is located in a cutting, and the subgrade, composed of yellowish fine sand, greyish, and greenish broad sandy channel showed water infiltration at $4.5 \mathrm{~m}$ in depth, with a similar drilling made in September 2015. Layer specifications are summarized in Table 1.

Table 1 - Layer characteristics of the studied sections.

$\begin{array}{lccc} & \text { Section 1 } & \text { Section 4 } & \text { Section 2 } \\ \text { Sublayer } & \text { Bituminous } & \text { Bituminous } & \text { Granular } \\ \text { Soil earthwork } & \text { Cutting } & \text { Embankment } & \text { Embankment } \\ \text { Soil type } & \text { Fine Sand } & \text { Clay } & \text { Clay }\end{array}$

\section{Continuous measurements on BPL Track}

As mentioned earlier, sensors in-place register continuous measurements irrespective of passing trains on the track. All the fast measurements of the sensors, recorded on the web-server are then post-processed using Scilab routines. The data treatment and processing plan and programs developed are detailed in the paper [12].

The slow measurements, recorded since the start of the project in October 2016, represent very valuable data for a better understanding of the different railway structures' behaviour and evolution in time. Seasonal evolutions of layer temperatures, moisture content evolutions, water infiltration, and track settlements can be analysed. Performance of sections with asphalt or granular sublayers can also be compared.

\section{(1) Temperature measurements}


Since the behaviour of bituminous mixtures is temperature-dependant, temperature represents a key parameter when analysing the behaviour of the bituminous layers. Temperatures probes were installed in sections 1 and 4 at the top and base of the asphalt concrete layer and at the base of the UGM layer of the structure. The measurements of all temperature probes are recorded every 15 minutes. Figure 5 and Figure 6 present, for section 4 and section 1 respectively, the temperature variations in the structure (daily minimum and maximum temperatures) in comparison with the ambient air temperatures (daily minimum and maximum temperature) recorded with the weather stations existing on all sites, and that for a period of 24 months between October 2016 and September 2018. Due to a technical error, recording of weather data has been suspended for 6 months, starting in June 2017, at site 4. For site 1, weather parameters have been recorded since April 2017.

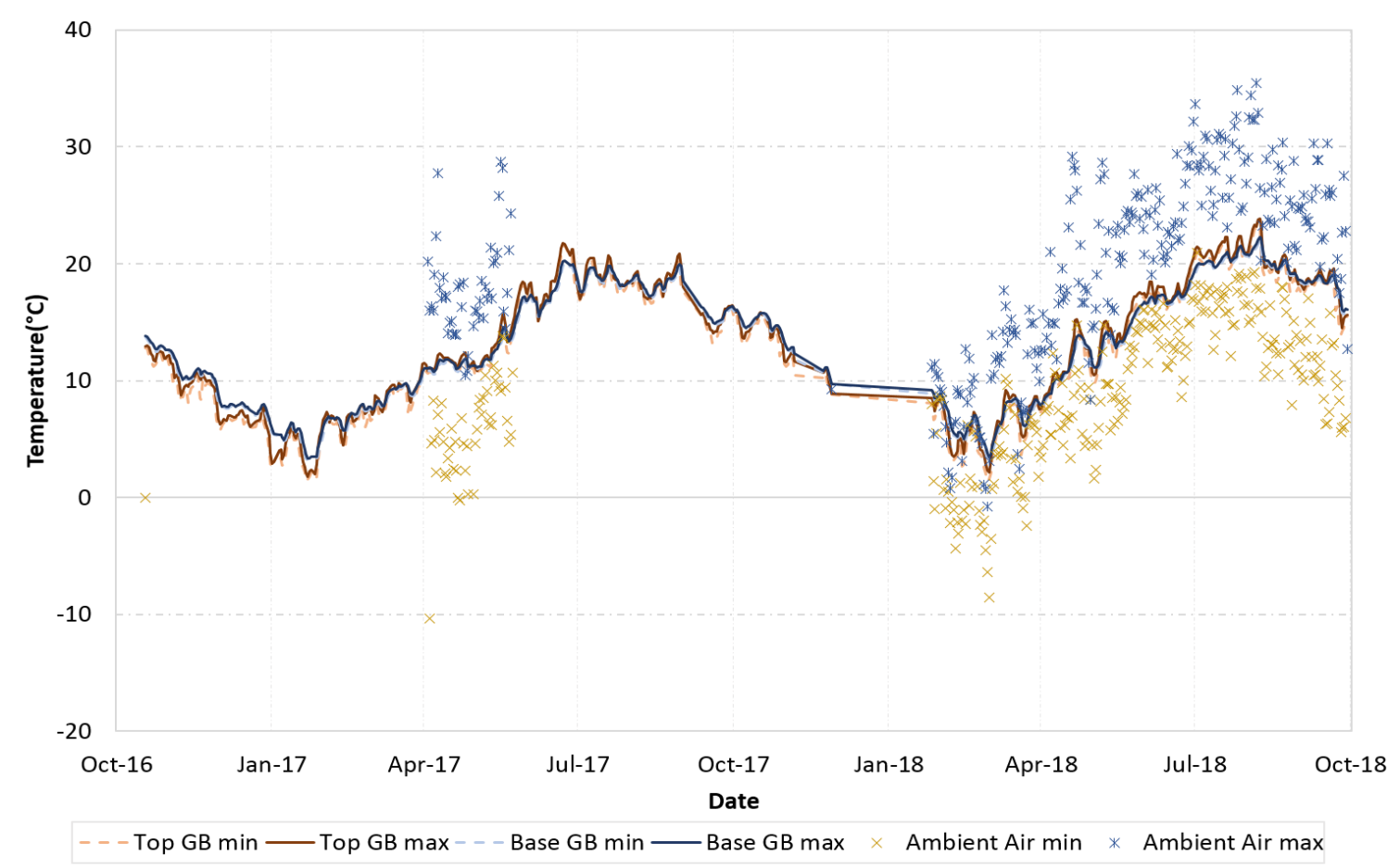

Figure 5. Bituminous layer and air ambient temperature evolutions (daily minimum and maximum values) in section 4 for two years 


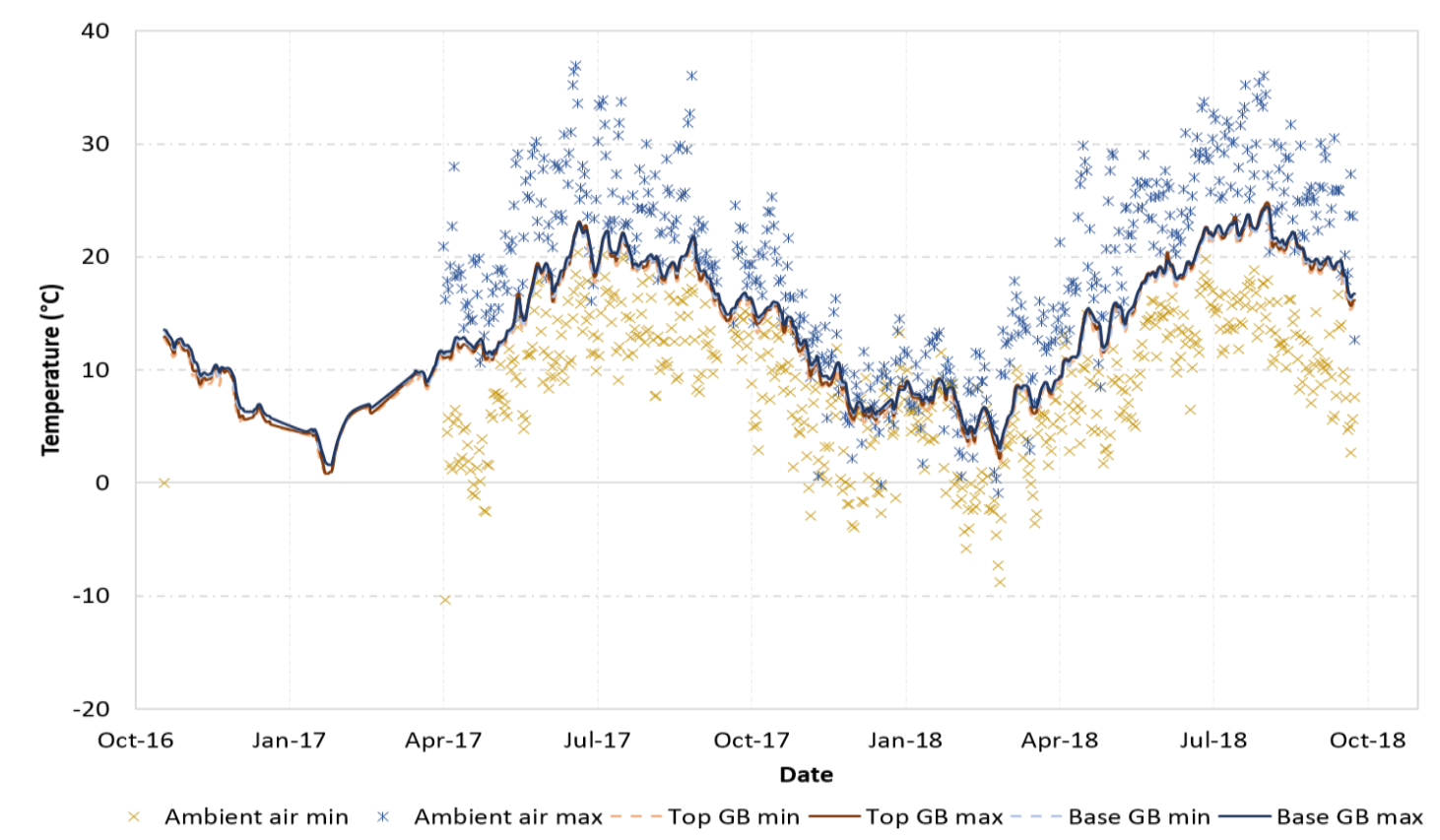

Figure 6. Bituminous layer and air ambient temperature evolution (daily minimum and maximum values) in section 1 for two years

The above graphs show the good repeatability of the measurements, and the typical seasonal temperature variations in the GB layers. In particular, the results show that, due to the insulation brought by the ballast layer, the temperature variations are considerably lower than the air temperature amplitudes. Indeed, the temperature values in the GB layer are close to the mean daily air temperatures (mean between the maximum daily peaks, in blue on the graphs, and the minimum daily peaks, in brown). While the highest air temperature attained is $37^{\circ} \mathrm{C}$ for both 2017 and 2018 summers, for section 1 and $36^{\circ} \mathrm{C}$ for summer 2018 at section 4, the maximum temperature value at the top of the GB layer reaches $24^{\circ} \mathrm{C}$. During winters, minimum values in the graphs indicate an air temperature minimum of $-9^{\circ} \mathrm{C}$ for both sites and an interval ranging from 1 to $3^{\circ} \mathrm{C}$ for the top of the asphalt concrete layer. [15] obtained similar temperature measurements for a bituminous sub-ballast layer in Kentucky, USA.

In conclusion, for the 2 years of monitoring, the maximum temperature of the bituminous layer was $24^{\circ} \mathrm{C}$ during the summer and the minimum temperature was $2^{\circ} \mathrm{C}$ 
in winter. This means that the bituminous material presents limited temperature variations, both in winter and summer. It never freezes, as no negative temperatures have ever been measured on the BPL instrumented sites. In summer, the temperature rarely exceeds $24^{\circ} \mathrm{C}$. [16] had already verified the anti-freeze protection role of the ballast.

Due to the ballast cover, the temperature range in the bituminous layer is much lower than what is observed in bituminous road pavements, where typical temperature variations in bituminous surface layers are between $-10{ }^{\circ} \mathrm{C}$ and $+60^{\circ} \mathrm{C}$, for climatic conditions of the North of France. These limited temperature variations in the railway structure are very favourable, as they limit the decrease of modulus of the bituminous layer, and the risk of rutting at high temperatures, and also the risk of thermal cracking at low temperatures.

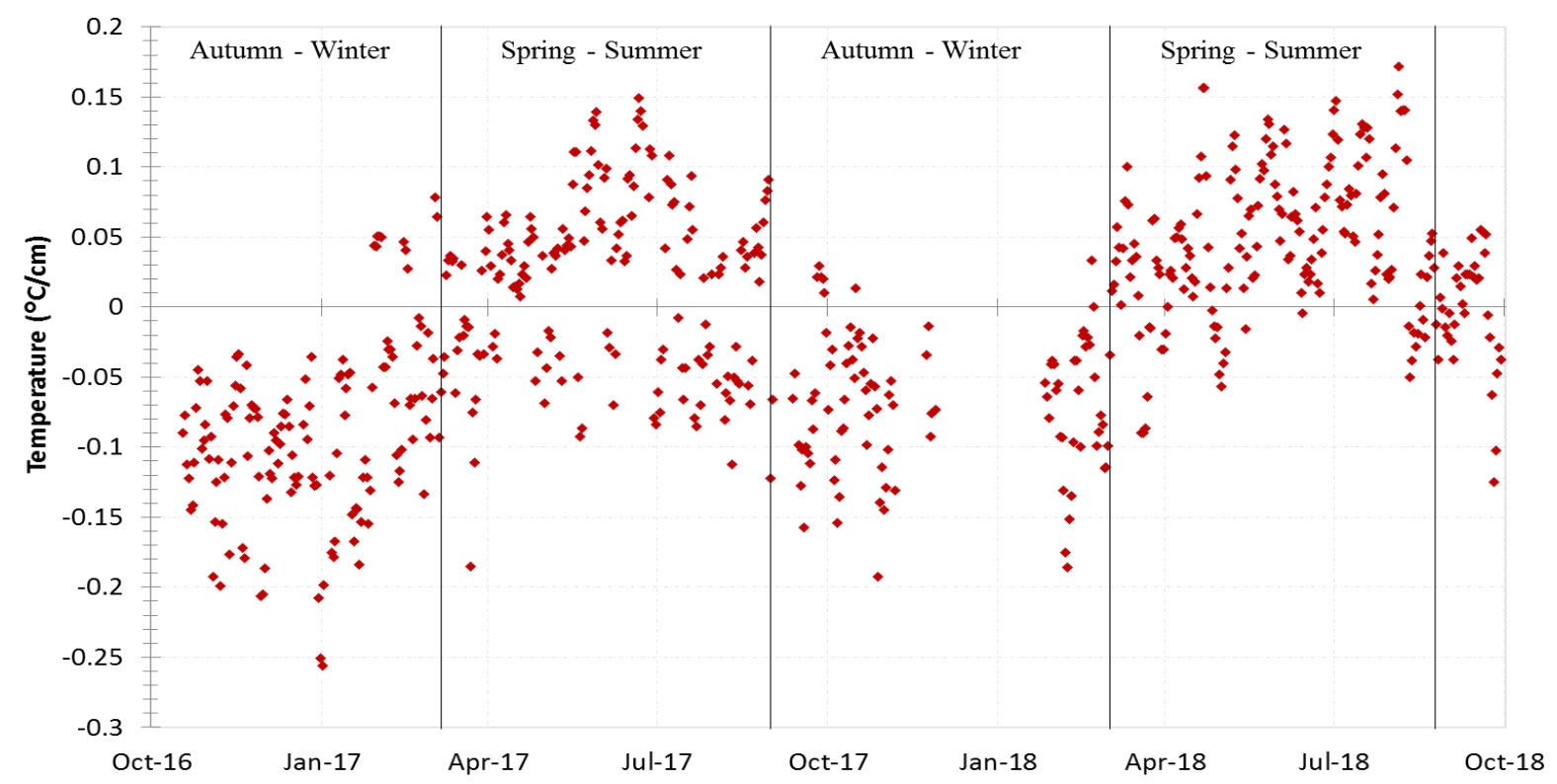

Figure 7. Temperature gradient between top and base of the GB layer in section 4

Figure 7 presents the variations of the temperature gradient between the top and the base of the $12 \mathrm{~cm}$ thick bituminous layer in the track structure of section 4 , for the period going from October 2016 to October 2018. Based on the two years of data, the 
calculated temperature gradients remain relatively low; in spring-summer periods, a gradient of $0.2{ }^{\circ} \mathrm{C} / \mathrm{cm}$ is never surpassed and the highest negative gradient in autumnwinter months is $-0.25^{\circ} \mathrm{C} / \mathrm{cm}$. These temperature gradients are again, much lower than the observed in road pavements, where values exceeding $1{ }^{\circ} \mathrm{C} / \mathrm{cm}$ are quite frequent.

\section{(2) Water content measurements}

Another important parameter for the performance of the railway track is the variations of moisture content in the subgrade, which can lead to a loss of bearing capacity, and an increase of deflections and settlements during humid climatic periods. The capacity of the sub-ballast layer to protect the subgrade from water infiltration is therefore important for the overall track performance. To evaluate the effect of the bituminous sublayer on the moisture conditions in the subgrade, four humidity probes were placed close to the top of the UGM layer, on each instrumented section of the BPL track; one between rails $(\mathrm{CH} 1)$, one under the sleepers distant $50 \mathrm{~cm}$ from the rails $(\mathrm{CH} 2)$, and two $180 \mathrm{~cm}$ away from the rails $(\mathrm{CH} 3$ and $\mathrm{CH} 4)$. In sections with asphalt sublayers, as section 4 illustrated in Figure 9, the asphalt concrete layer covers the probes designated by $\mathrm{CH} 1$ and $\mathrm{CH} 2$. To analyse the influence of the GB sublayer on water infiltration in the railway track, measurements made during two rainy days are compared in Figure 8 and Figure 9. The histograms define cumulative rain heights recorded on September $9^{\text {th }}$, 2017 for the granular section (Figure 8) and on September $13^{\text {th }}, 2017$ for the bituminous section (Figure 9). The total rain heights were similar on the two sections: $28 \mathrm{~mm}$ on section 2 , and $23 \mathrm{~mm}$ on section 4 . 


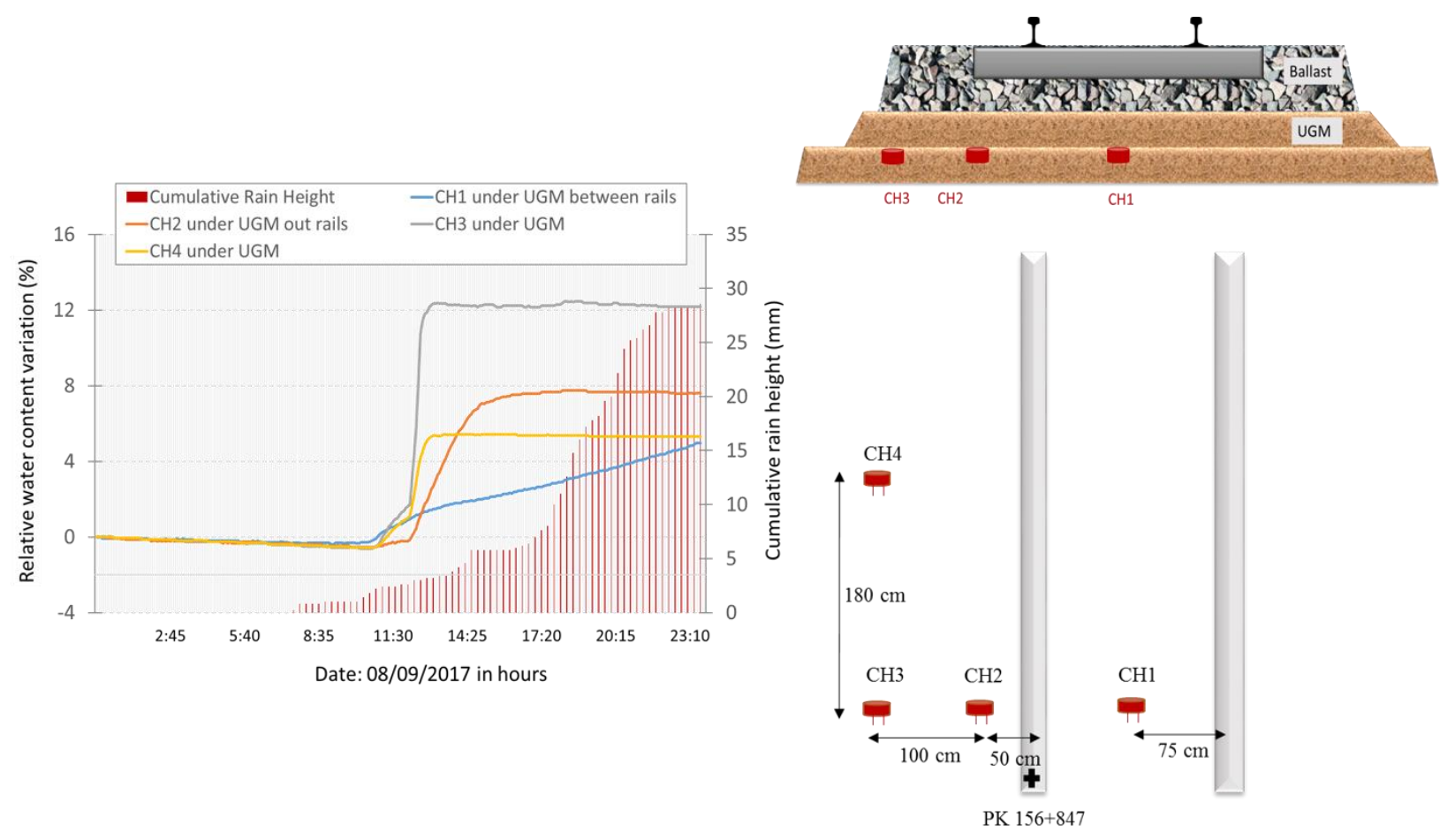

Figure 8. Water content variations measured in section 2 (with granular sublayer)

As shown in Figure 8, for the granular section, water contents in the UGM layer increase rapidly during the rain event, indicating water infiltration, due to the relatively high permeability of the granular sublayer. For probes $\mathrm{CH} 3$ and $\mathrm{CH} 4$, located close to the edge of the track structure, and not covered by the sleepers, the water content increase is particularly rapid, and reaches quickly a maximum value (after about 1 to 2 hours), indicating that the material is saturated. For probe $\mathrm{CH} 2$, covered partially by the sleepers, water content increases more slowly, but saturation is also attained. Finally, the curve of the probe placed between rails $\mathrm{CH} 1$, covered totally by the sleeper, presents a much lower slope and indicates a continuous increase in water content during the observation period. Thereby, the sleepers reduce the water infiltration rate in the track substructure.

The situation is quite different in the section with asphalt sublayer, as indicated on Figure 9. Probes placed under the asphalt concrete $(\mathrm{CH} 1$ and $\mathrm{CH} 2)$, in the UGM layer, 
show practically no change of water content. For probes $\mathrm{CH} 3$ and $\mathrm{CH} 4$, placed close to the edge of the structure, and not covered by the asphalt layer, the water content increases with the height of rain (which attained $23 \mathrm{~mm}$ during that day), but never reaches complete saturation. This could be explained by the bituminous coating applied on top of the UGM layer, at the side of the GB layer, which also limits water infiltration.
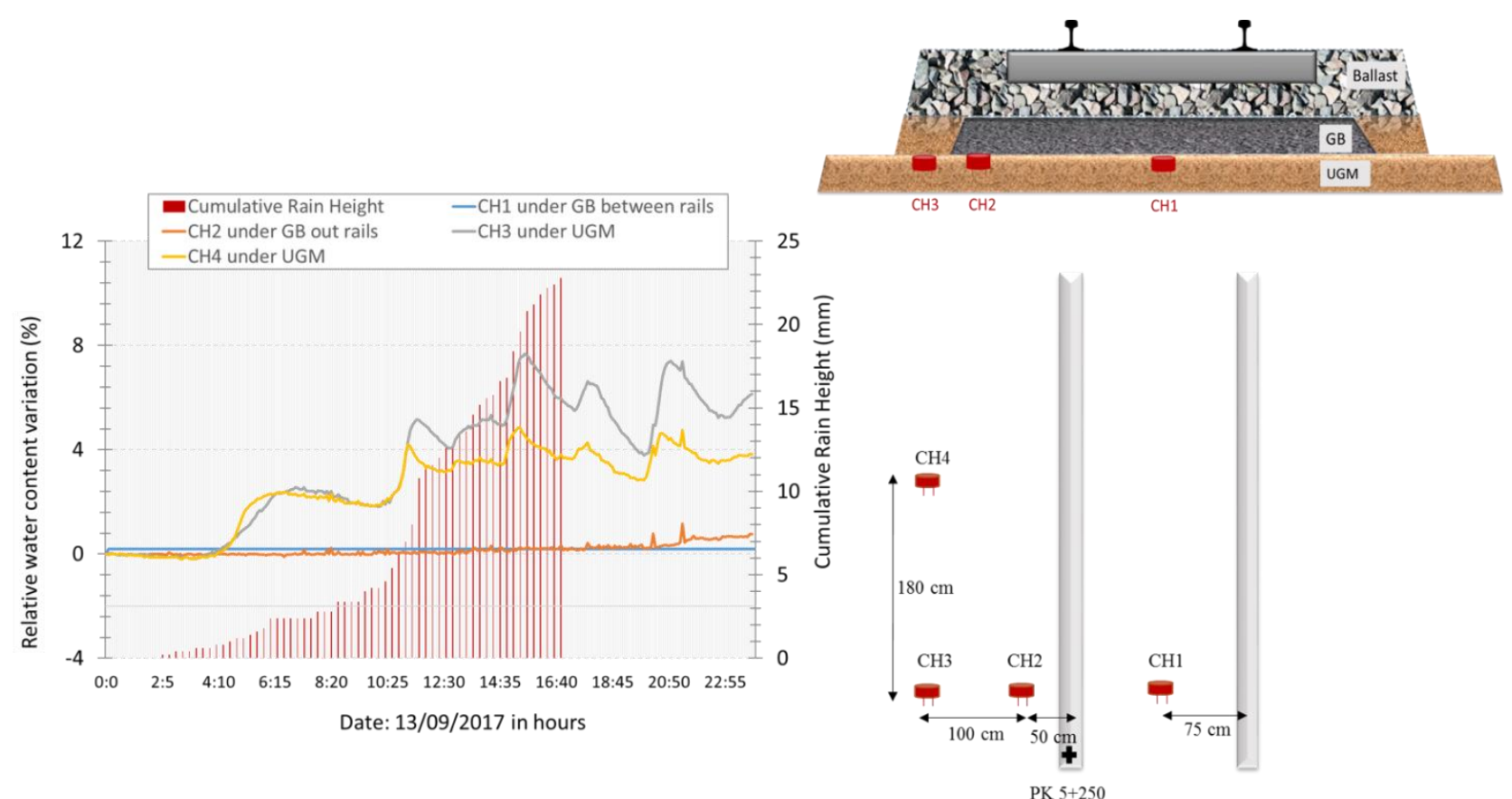

Figure 9. Water infiltration in section 4 (with bituminous sublayer)

These results show that the bituminous sublayer ensures a very good protection against water infiltration into the subgrade. They are in agreement with the results of [17] work where it has been demonstrated that the use of bituminous sub-ballast leads to a lower variation in the moisture content of the bed layers.

Figure 10 presents long-term water content variations measured on the 3 instrumented sections, during 14 months of monitoring. Average water content values calculated by periods of 10 days are presented. The results indicate no marked seasonal water content variations, but there are clear differences between the results obtained on the 3 sections: 
- On section 2, with a granular sublayer, all 4 probes indicate similar long term water content variations. Therefore, there is no significant difference between the long-term water contents observed under the center of the track, and close to the edge. Overall, the water contents vary between $5 \%$ and $11 \%$ approximatively.

- On section 1 , with a bituminous sublayer, under the center of the track, the water content remains practically constant, and close to $4 \%$ (probe $\mathrm{CH} 1$ ). Near the edge of the track, the water content variations are more important: For probe $\mathrm{CH} 2$, located still under the bituminous sublayer, but close to its border, the water contents vary between $4.5 \%$ and $7.5 \%$. Similar variations are obtained for probe $\mathrm{CH} 3$, located beyond the edge of the bituminous layer, under granular material only. For probe $\mathrm{CH} 4$, located also at the edge of the track, the water contents vary between $5 \%$ and $11 \%$, and are similar to those measured on section 2, with a granular sublayer.

- On section 4, with a bituminous sublayer, water content variations are lower than on section 1 due to soil's material differentiation (Table 1) and to soil earthwork conditions (section 1 on cutting and section 4 on embankment). 
(a)

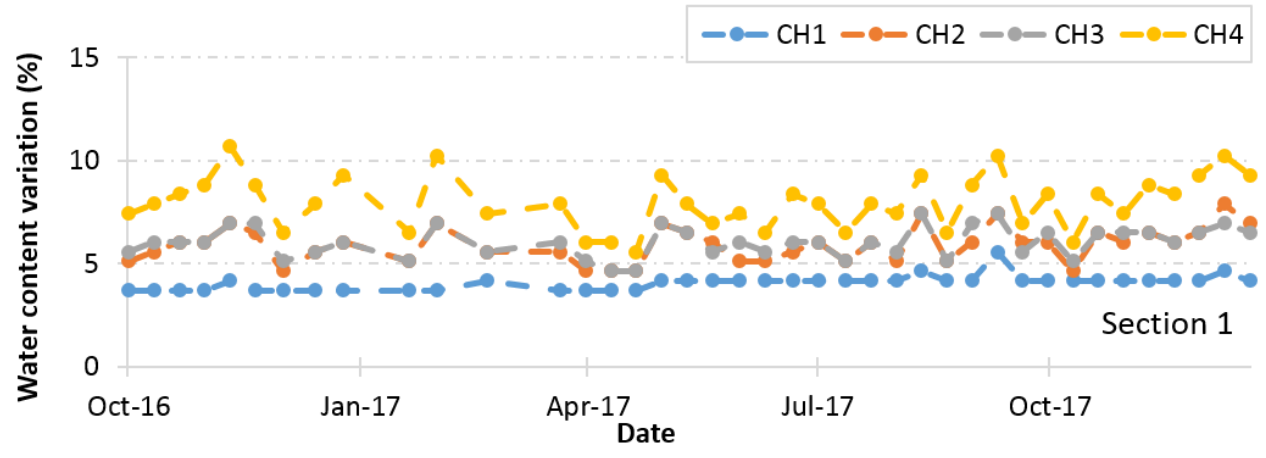

(b)

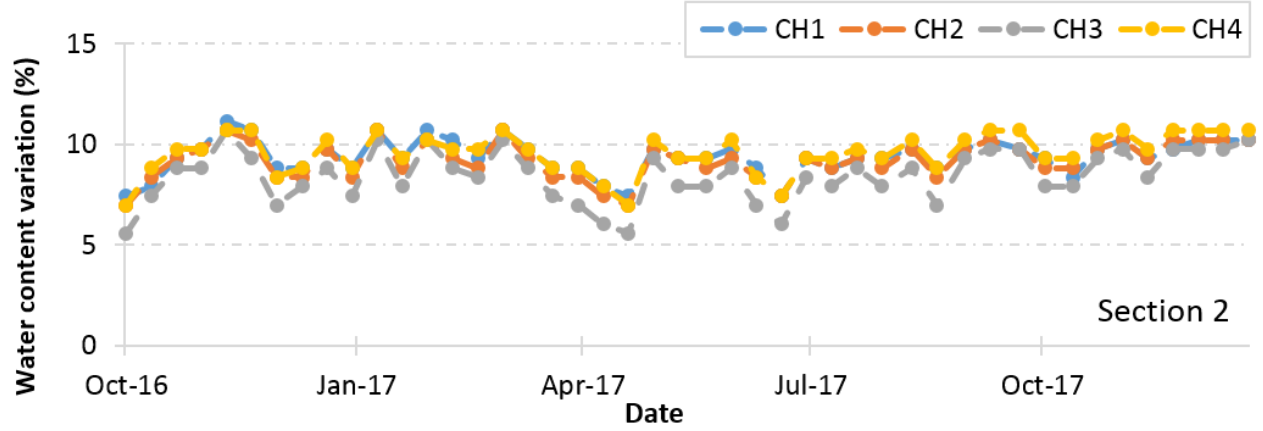

(c)

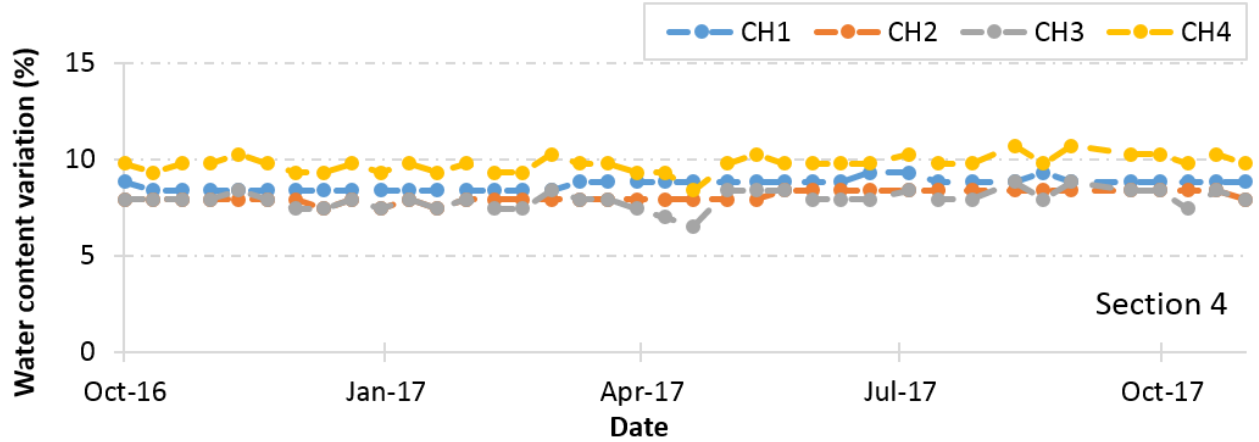

Figure 10. Long-term water content variations on the 3 instrumented sections, between October 2016 and November 2017

\section{(3) Vertical displacement measurements}

Two anchored displacement sensors 6/7 $\mathrm{m}$ distant have been installed in each section.

These sensors consist of an LVDT, which body is fixed to the top of the bituminous layer (the red hatched part), and a rod, the movable part, anchored at a depth of $6 \mathrm{~m}$, to which the core of the LVDT is connected as illustrated in Figure 11. Level variation between both parts indicates the displacement registered. Thus, the sensor measures the vertical displacement of the whole structure under the ballast, up to a depth of $6 \mathrm{~m}$. 


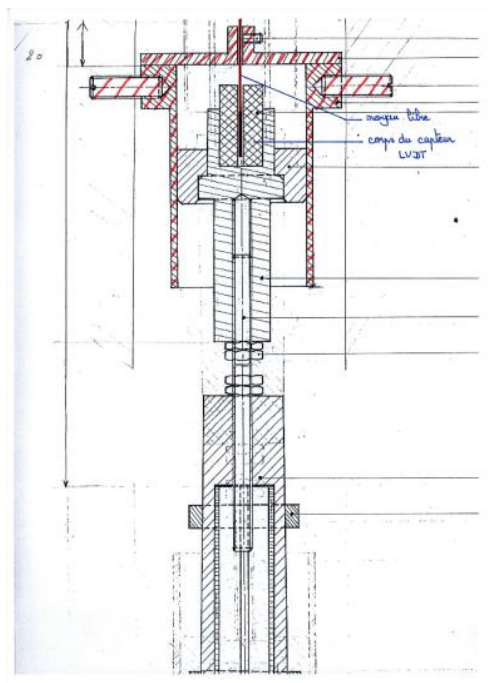

Figure 11. Scheme of the anchored displacement sensor

Unlike others, the vertical displacement sensors are used to measure both the transient deflections under the passing trains, and the long-term vertical displacements known for settlements of the track. Figure 12 illustrates the deflection signal of a train passing on the track of section 2 (with granular sublayer) on May 17, 2017 at a speed of $270 \mathrm{Km} / \mathrm{h}$. It is a single high-speed train, with 13 bogies, and the peaks corresponding to the different bogies can be clearly identified on the deflection signal.

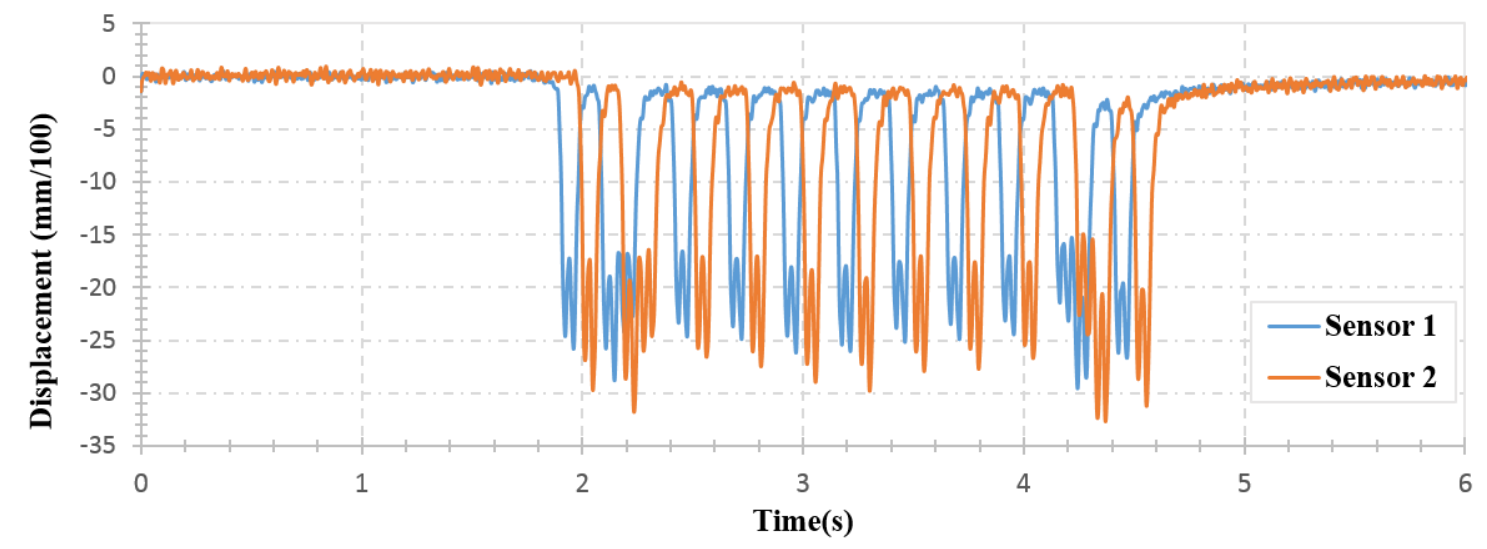

Figure 12. Deflection signal of a simple train passing on $H S L$ BPL at a speed $V=270 \mathrm{Km} / \mathrm{h}$

Figure 13 shows the deflection signal of a double train passing on the same day and on the same section (with granular sublayer), but at a speed of $217 \mathrm{Km} / \mathrm{h}$. The double train signal points well the 26 bogies of the high-speed train with 26 downward peaks. The 
good repeatability of the measurements of both anchored displacement sensors and the good definition of the signals show the reliability of the data recorded by the sensors.

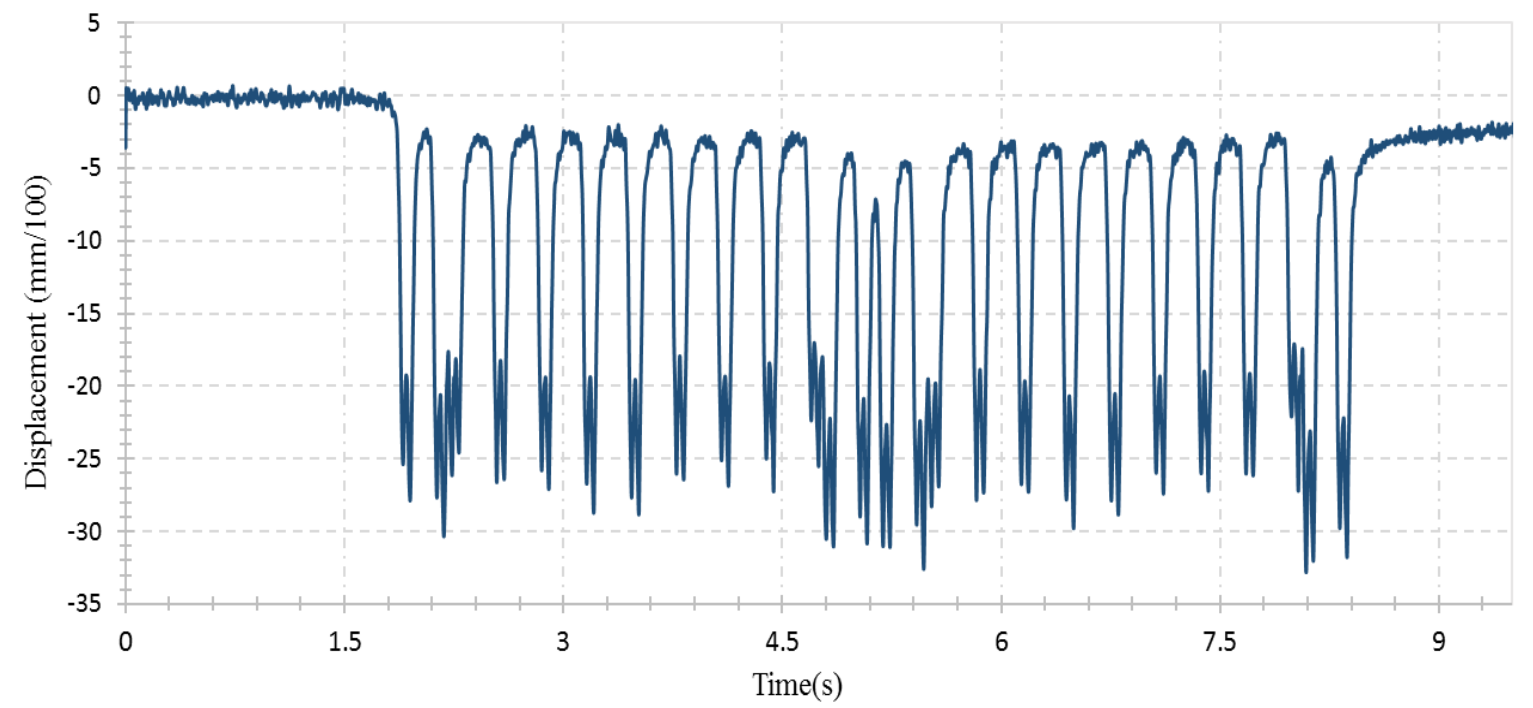

Figure 13. Deflection signal of a double train passing on $H S L$ BPL at a speed $V=217 \mathrm{Km} / \mathrm{h}$

In addition to the deflection measurements, the anchored displacement sensors also record the long-term vertical displacements of the railway structures. The vertical displacements recorded on all instrumented sections from October 2016 to September 2018 are summarised on Figure 14. The curves represent the vertical settlements of the track, during the first two service years, for the conventional and the innovative structures of the BPL HSL.

As the subgrade contributes largely to the settlements of the track, it is important to note the characteristics of the soils present on the different sections, described earlier in Table 1. The subgrade of section 2 (granular sublayer) and section 4 (bituminous sublayer) consist mainly of clay. Contrarily, the soil of section 1 (bituminous sublayer) is composed of fine sand. For the following analysis, it is also important to remind that traffic is identical on all sections, and that weather conditions are similar, sections 1 and 
4 being close to each other (about $20 \mathrm{~km}$ ), and section 2 being at a distance of approximately $120 \mathrm{~km}$.

(4) The first observation that can be made on Figure 14 is that there is a change in the evolution of the vertical settlements in July 2017, which corresponds to the date of opening of the BPL track to commercial traffic. Before July 2017, the traffic was limited to different test phases. After opening to traffic, various types of trains loaded differently (almost 30 trains daily) have been crossing the line, at a commercial speed of $320 \mathrm{~km} / \mathrm{h}$. A slight settlement increase is noticeable on all sections after this date, and seems to be more important on the sandy section (1). Two anchored sensors have stopped working at an early stage: sensors $n^{\circ} 1$ of sections 1 and 4.

(5) The graphs of Figure 14 do not indicate any significant soil consolidation, which would most likely lead to a steady settlement over the entire period. There is also no significant difference between the settlements observed on the bituminous sections, compared with the granular section. However, analysing precisely the soil movements is not obvious, as the water content variations are not known (water content probes have been installed only in the unbound granular layer).

(6) However, Sections 2 (with granular sublayer) and 4 (with bituminous sublayer) seem to have the same seasonal behavior: some swelling (probably due to moisture content increase) seems to occur during wintertime, and some shrinking during summer time, leading to a slight downward displacement. This is probably related with the clay soil present on these two sections. The displacements observed on section 1 (with bituminous sublayer), with a sandy 
soil, are in the opposite direction: settlements are observed during the winter, and a slight uplift is observed during the summer.

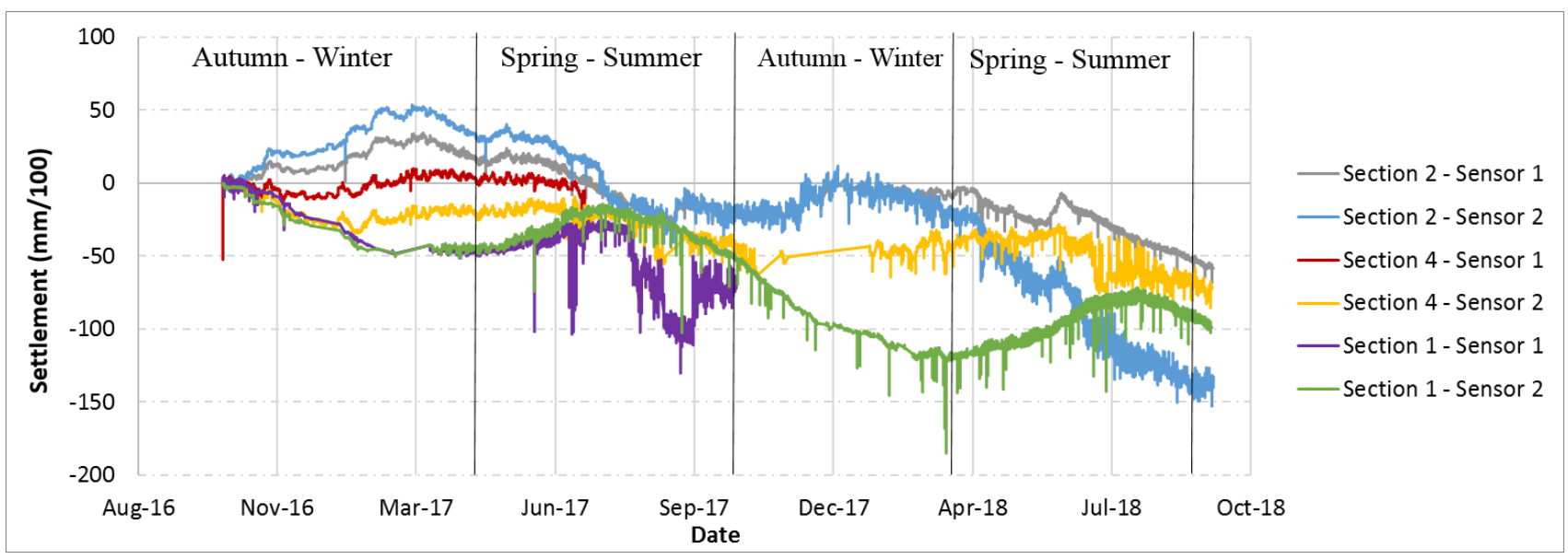

Figure 14. Evolution of the track settlement of sections 1, 2 and 4 for two years

Globally, it can be concluded from the curves in Figure 14, that the settlements observed during the two-year period are very low for all the sections, ranging from 0.5 to $1.5 \mathrm{~mm}$. These values are by far lower than the settlement criteria set by SNCF for high-speed railway tracks (maximum settlement $10 \mathrm{~mm}$ ).

\section{Comparison of BPL railway track measurements with pavement measurements}

Bituminous mixes are used mainly for construction of road pavements, and their behaviour in this field is well known. Temperature is a key parameter for the behaviour of bituminous materials. Indeed, bituminous materials present a high temperature susceptibility, due to the properties of bituminous binders. When temperature increases, the stiffness of bituminous mixes decreases, and their permanent deformations increase [18-19].

To evaluate the performance of bituminous layers in railway tracks, it is interesting to compare environmental conditions to which there are submitted in railways, and in road pavements. 
IFSTTAR has instrumented an experimental pavement section in Nantes (France), with different temperature probes (at the surface and at 5 and $10 \mathrm{~cm}$ depth) to monitor temperature variations. The test section consist of a $10 \mathrm{~cm}$ thick GB4 layer, on a UGM base layer.

Distance between Nantes and the BPL sites in Le Mans is estimated to $180 \mathrm{~km}$, sufficiently close to have similar climatic conditions, for the comparisons.

Figure 15 compares the daily minimum and maximum temperature values recorded at the top of the Nantes bituminous pavement and at the top of the bituminous sub ballast layers on the BPL track.

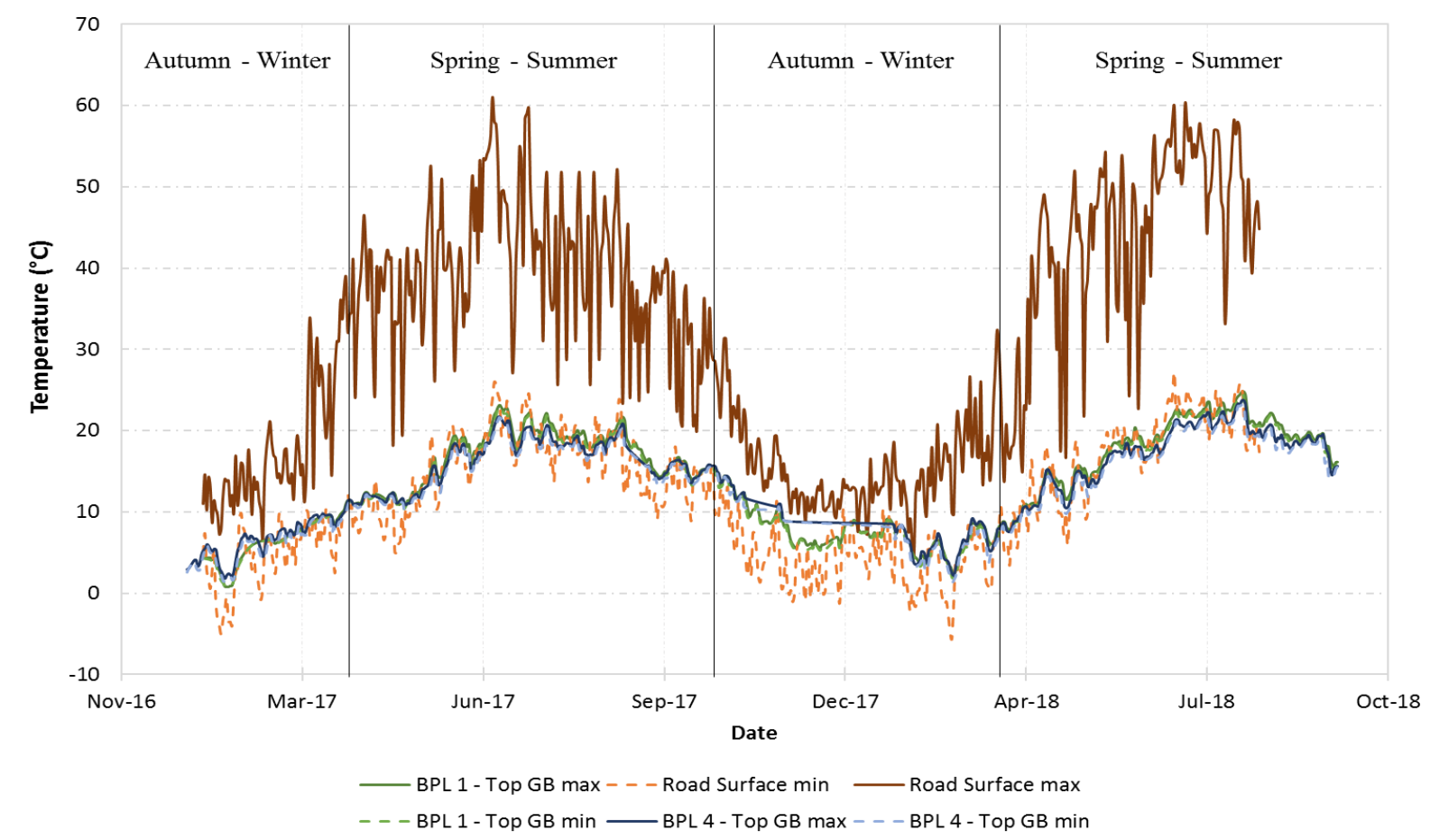

Figure 15. Comparison of temperature variation rate between pavement and railways track GB mixtures

As it was presented on Figure 15, the green and blue curves corresponding to BPL bituminous sections 1 and 4 , register $22^{\circ} \mathrm{C}$ as highest temperature near during the hottest summer periods and $2{ }^{\circ} \mathrm{C}$ as lowest temperatures during the winter. In comparison, at the surface of the road pavement, the temperature can reach about $60^{\circ} \mathrm{C}$ in summer and $-6^{\circ} \mathrm{C}$ in winter. The top of the GB layer in road pavements presents, in 
particular, much higher temperature values in the summer than the bituminous sublayer in railway structures. The ballast layer limits considerably the daily and seasonal temperature variation in the bituminous sublayer.

The temperature gradients in the asphalt concrete layer of the road pavement are presented in Figure 16, in comparison to the gradients calculated in the railway sublayers of BPL. The differences between the two types of structures are again very significant. The two curves show similar trends, with mainly positive temperature gradients (higher surface temperatures) in the spring-summer, and negative gradients in autumn - winter, but with very different levels. For the road structure, temperature gradients reach maximum positive values of $+2{ }^{\circ} \mathrm{C} / \mathrm{cm}$ and minimum negative values of $-0.5^{\circ} \mathrm{C} / \mathrm{cm}$, while the maximum and minimum values found for BPL HSL are + $0.15^{\circ} \mathrm{C} / \mathrm{cm}$ and $-0.2^{\circ} \mathrm{C} / \mathrm{cm}$. In the railway structure, the temperature gradients can be neglected, and a constant temperature can be considered in the bituminous layer for design or modelling purposes, which is not possible for the road structure.

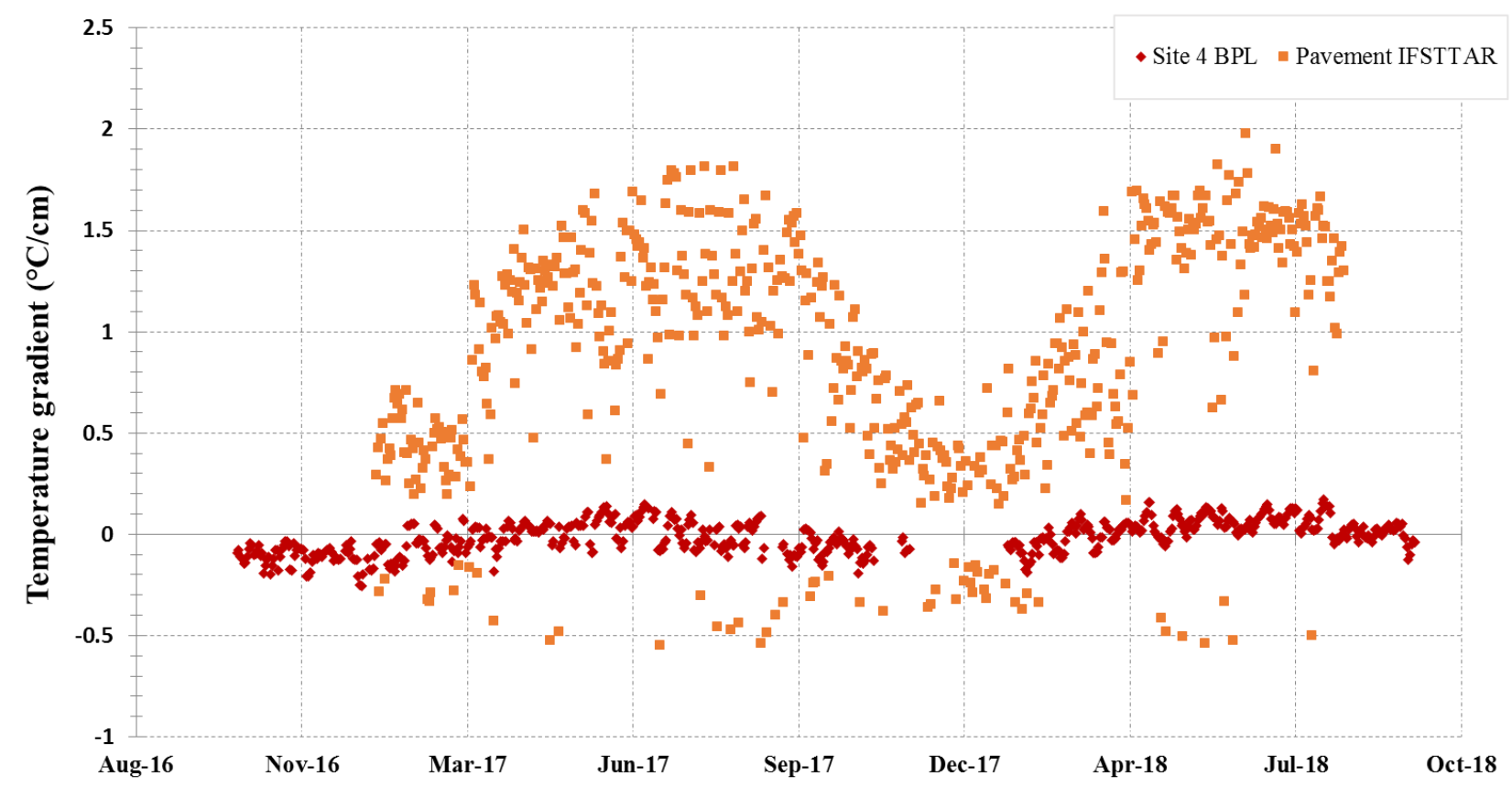

Figure 16. Gradient temperature between top and base of the pavement track's bituminous mixture 
Furthermore, modulus variations corresponding to the temperature variations recorded in the GB4 material at a frequency of $10 \mathrm{~Hz}$ are compared in Table 2 for the road pavement and for the bituminous sublayer of the railway track BPL. It can be seen that the amplitude of modulus variations is considerably reduced in the railway track, which should considerably reduce risks of deterioration phenomena due to high temperatures (rutting) or low temperatures (thermal cracking), common on road pavements, and thus ensure a high durability of the bituminous sublayer in railway structures.

Table 2 - Modulus variations of GB4 with respect to temperature

\begin{tabular}{|l|c|l|r|r|}
\hline & \multicolumn{2}{|c|}{ Road pavement } & \multicolumn{2}{c|}{ HSL BPL } \\
\hline Temperature & $\mathrm{T}^{\circ} \max : 60^{\circ} \mathrm{C}$ & $\mathrm{T}^{\circ} \min :-6^{\circ} \mathrm{C}$ & $\mathrm{T}^{\circ} \max : 22^{\circ} \mathrm{C}$ & $\mathrm{T}^{\circ} \min : 2^{\circ} \mathrm{C}$ \\
\hline $\begin{array}{l}\text { Modulus of } \\
\text { GB4 (at 10Hz) }\end{array}$ & $1067 \mathrm{MPa}$ & $23000 \mathrm{MPa}$ & $6860 \mathrm{MPa}$ & $18860 \mathrm{MPa}$ \\
\hline
\end{tabular}

\section{Conclusion}

The aim of this paper was to examine mechanical performance of bituminous subballast layers, on the new high-speed "Bretagne - Pays de Loire" line. On this line, three main experimental sections have been instrumented and monitored during two years. These sections include two structures with bituminous sublayers under the ballast, and one structure with a classical granular sublayer, which served for comparison. Only "slow" measurements including temperature and moisture content measurements, and also vertical settlements, have been analysed in this paper. In addition, comparisons between temperature variations in the railway track and in a road pavement have been made.

Based on the results obtained in this study, the following conclusions can be drawn: 
- Settlements on all BPL HSL sections, whether bituminous or conventional, range from 0.5 to $1.5 \mathrm{~mm}$ after two years, and are found to be minimal according to SNCF rules for railway design. No significant difference has been observed between the settlements observed on the structures with bituminous sublayer, compared with the traditional granular section.

- The interest of the bituminous sublayer for improving water drainage and protecting the embankment body from rainwater infiltration is clearly demonstrated. Application of an asphalt sublayer reduces the infiltration of water into the bed layers of the railway track, thereby avoiding problems of loss of bearing capacity and deterioration of the subgrade during rainy periods.

- Considering the importance of temperature in both mechanical performance and service life of bituminous mixture, the results confirm that temperature variations are considerably limited in innovative bituminous sublayers of railway tracks, despite severe environmental and climatic conditions.

- In the case of a ballasted track, if the ballast completely covers the bituminous layer, it protects the bituminous mixture from UV exposition and ambient air heat, but not from moisture infiltration. According to this study and IFSTTAR's experiments on road pavements reviewed in this paper, the bituminous layer seems to be well protected from extreme temperature variations in a sub-ballast position. In comparison with road pavements, this should considerably limit deterioration phenomena like rutting, due to high temperatures, and thermal cracking, due to large temperature variations.

According to all the above, the use of asphalt layers in railway construction contributes effectively to the protection of the subgrade from water infiltration. In addition, the ballast layer plays an important role in protecting the sub-ballast layers from 
temperature variations. Thus, temperature variations in bituminous sublayers on ballasted railway tracks are considerably reduced, compared with road pavement conditions, which enhances the interest of using asphalt layers for railway applications. To complete the results presented here, which were mainly focused on the evaluation of climatic effects, and long term settlements, studies are also under way to evaluate the effect of the bituminous sublayer on dynamic track response (accelerations and strains under train loading) [20] . 


\section{References}

[1] Pita, A.L., Teixeira, P.F., and Robusté, F. (2004). High speed and track deterioration: the role of vertical stiffness of the track. Proc. Inst. Mech. Eng. Part F J. Rail Rapid Transit 218, 31-40.

[2] Quezada, J.C. (2012). Mécanismes de tassement du ballast et sa variabilité.

[3] Saussine, G. (2004). Contributiona la modélisation de granulats tridimensionnels: application au ballast. These Dr. LMGC Montp.

[4] Suiker, A.S.J. (2002). The mechanical behaviour of ballasted railway tracks.

[5] Robinet, A., and Cuccaroni, A. (2012). L'expérience grave-bitume de la LGV Est européenne. Rev. Générale Chemins Fer 44-50.

[6] European Asphalt Pavement Association (2003). Asphalt in railway tracks. EAPA Position Pap. 5-11.

[7] Chupin, O., and Piau, J.-M. (2011a). Modeling of the dynamic response of ballast in high-speed train structures. p. pp-712.

[8] Chupin, O., and Piau, J.-M. (2011b). Modélisation de la réponse dynamique d'une structure ferroviaire multicouche sous chargement roulant. p. $6 \mathrm{p}$.

[9] Le Cam, V., Lemarchand, L., Martin, W., and Bonnec, N. (2010). Improving wireless sensor behavior by means of generic strategies. Struct. Health Monit. 1, 696703.

[10] Martin, A. (2014). Analyse numérique de la réponse dynamique de structures ferroviaires. Application à la réduction des désordres géométriques induits dans les couches de ballast des Lignes à Grande Vitesse.

[11] Khairallah, D., Blanc, J., Cottineau, L.M., Hornych, P., Hosseingholian, M., Ducreau, A., Pouget, S., and Voignet, P. (2017). Monitoring of railway structure with bituminous underlayment. GEORAIL 2017 3ème Symp. Sur Géotechnique Ferrov.

[12] Khairallah, D., Blanc, J., Hornych, P., Cottineau, L.M., Hosseingholian, M., Pouget, S., Ducreau, A., and Voignet, P. (2018). Monitoring of railway structures HSL BPL with bituminous layer. Proc. 7th Transp. Res. Arena TRA 2018 April 16-19 2018 Vienna Austria.

[13] Blanc, J., Hornych, P., Duong, N.S., Blanchard, J.-Y., and Nicollet, P. (2019). Monitoring of an experimental motorway section. Road Mater. Pavement Des. 20, 74 89.

[14] Duong, N.S., Blanc, J., Hornych, P., Bouveret, B., Carroget, J., and Le Feuvre, Y. (2018). Continuous strain monitoring of an instrumented pavement section. Int. J. Pavement Eng. 1-16.

[15] Rose, J.G., Li, D., and Walker, L.A. (2002). Tests and evaluations of in-service asphalt trackbeds. p. 
[16] Trinh, V.-N., Calon, N., Tang, A.M., Cui, Y.-J., Dupla, J.C., Canou, J., Robinet, A., Lambert, L., and Schoen, O. (2011). Caractérisation hydromécanique des matériaux constitutifs de plates-formes ferroviaires anciennes. pp. 377-388.

[17] Rose, J.G., and Bryson, L.S. (2009). Hot mix asphalt railway trackbeds: trackbed materials, performance evaluations, and significant implications. p. 19.

[18] Olard, F., Di Benedetto, H., Dony, A., and Vaniscote, J.-C. (2005). Properties of bituminous mixtures at low temperatures and relations with binder characteristics.

Mater. Struct. 38, 121-126.

[19] Benedetto, H.D., Delaporte, B., and Sauzéat, C. (2007). Three-dimensional linear behavior of bituminous materials: experiments and modeling. Int. J. Geomech. 7, 149157.

[20] Khairallah, D., Blanc, J., Cottineau, L.M., Hornych, P., Piau, J.-M., Pouget, S., Hosseingholian, M., Ducreau, A., and Savin, F. (2019). Monitoring of railway structures of the high speed line BPL with bituminous and granular sublayers. Constr. Build. Mater. 211, 337-348. 